\title{
Blood Products Collection Facility
}

National Cancer Institute

\section{Source}

National Cancer Institute. Blood Products Collection Facility. NCI Thesaurus. Code

C133301.

A facility that performs blood collections or apheresis. 